\title{
Symbolism in Marketing Systems
}

\author{
Djavlonbek Kadirov' and Richard J. Varey ${ }^{2}$
}

@SAGE

\begin{abstract}
The article explores the different aspects of the symbolism of marketing systems. The authors argue that marketing systems maintain distinctive symbolic structures in addition to their functional/operational structures; the environment is an inherent part of the system rather than being outside the system; and symbolic unfolding, that is, the process through which emerging systems address the symbolic controversies of existing systems, underlies the formation of new marketing subsystems. Two implications for macromarketing research are drawn (I) improving the standards of living via making product assortments (that are also symbolic) available to consumers in fact is an unending quest of addressing acute societal problems and contradictions and (2) the design of marketing systems is likely to fail if the symbolic character of a system under development is not taken into account.
\end{abstract}

\section{Keywords}

marketing systems, symbolism, meanings, symbolic unfolding, hybrid cars

The main purpose of this article is to extend our understanding of the symbolic (i.e., meanings) dimension of marketing systems. Conceptualizing marketing systems is a central research orientation in macromarketing (2006; Layton 2007; Fisk 1967; Alderson 1965; Dixon and Wilkinson 1982; Meade II and Nason 1991). Furthermore, it is widely recognized that marketing systems are multidimensional (Mittelstaedt, Kilbourne, and Mittelstaedt 2006; Layton 2007). Hence, marketing systems can be studied in different crosscuts and dimensions (Layton and Grossbart 2006). For instance, the aggregation dimension represents marketing systems that range from highly aggregated (e.g., global systems and trade blocks) to moderately aggregated (e.g., firms and households) to disaggregated (e.g., exchange; Layton, 2007). The structural approach examines yet another dimension that comprises the interrelation of structural parts of marketing systems: trade flows (Layton 1981; Tuninga 1991), transvections (Alderson 1965), marketing channels (Olsen and Granzin 1990; Mittelstaedt and Stassen 1994), and spatial systems (D’Rozario and Williams 2005; Ingene 1983; Markin and Duncan 1981). The temporal dimension of marketing systems is captured by historical research (see Jones and Shaw 2006) and future sustainability concerns (Dolan 2002; Kilbourne, McDonagh, and Prothero 1997; van Dam and Apeldoorn 1996). The geographic dimension emerges from studies on different national and local market systems (Dahringer and Hilger 1985; Etgar 1983; Speece 1990; Ortiz-Buonafina 1992). Mittelstaedt et al. (2006) in their article on Macromarketing as Agorology offer a number of different dimensions for macromarketing research, one of them being the "antecedents heterogeneity tradition" (p. 135). The authors argue that the tradition unifies research on formal, informal, and philosophical antecedents to the formation of marketing systems. The list of dimensions and underlying perspectives can be extensive (see Layton and Grossbart 2006).

In this article, the authors focus on the meanings dimension. The research on meanings has been fragmental in macromarketing (Kilbourne et al. 1997; Schaefer 2005; Venkatesh 1999; Holbrook 1995; Arndt 1986). Arndt (1986) argued that production systems (he refers to them as interorganizational networks) largely operate based on cultural meanings. Kilbourne et al. (1997) examined the effect of societal beliefs and interpretive structures on the relationship between consumption and quality-of-life perceptions. Although the authors assumed that (sustainable) consumption is only for utilitarian purposes, they recognized that social systems are essentially ideological, and thus symbolic. Schaefer and Crane (2005) accepted the possibility of two types of conceptualization: the behavioral view and the anthropological view of consumption. The former takes consumption as a rational choice process, whereas the latter conceptualizes consumption as a hedonistic, identity-building, and communication process. Dolan (2002) argued that consumption activities are mainly symbolic and culture-laden because people tend to approach products as cultural artifacts. Even the utility of the product per se can also be taken as a cultural symbol (i.e., an interpreted aspect of the

\footnotetext{
'School of Business, Eastern Institute of Technology, New Zealand

${ }^{2}$ Waikato Management School, University of Waikato, New Zealand

Corresponding Author:

Djavlonbek Kadirov, Eastern Institute of Technology, School of Business, Faculty of Applied Science, Business and Computing, Private Bag 1201, Hawke's Bay Mail Centre, Napier 4142, New Zealand

Email: dkadirov@eit.ac.nz
} 
product). Venkatesh (1999) examined the macromarketing implications of the postmodernist view and discussed marketing systems as part of the global sign economy. According to his perspective, not only consumption activities but also practices in the domain of production and distribution are increasingly becoming symbolic.

What is a marketing system if seen from the prism of the meaning perspective? In addressing this question, the authors offer an alternative explanation to the formation and operation of marketing systems. Our explanation is rooted in the synthesis of readings from anthropology (Bateson 1991; McCracken 1988; Geertz 1983), sociology (Luhmann 1989, 1995), cybernetics (von Foerster and Poerksen 2001), and philosophy (Wittgenstein 1963; Bernstein 1983). The authors explain marketing systems (in both abstract and concrete forms) as flows of interpretive action. In other words, activities like creating, offering, moving, communicating, consuming, and disposing of product assortments are interpretive practices in essence. These practices represent not only symbol interpretation (reading "signs" in Venkatesh's terms) but also symbol generation for the purpose of subsequent interpretation.

Concurring with Venkatesh (1999) in his arguments on recent postmodern developments, the authors argue that (1) marketing systems are symbolic in essence and they can be defined as spaces of marketplace meaning creation; (2) the environment is an inherent (interpreted) feature of the system and it represents the system actor's unique perspective to understanding other symbolic (both marketing and nonmarketing) systems; (3) the symbolic unfolding process is at work in which a marketing system emerges from the environment as a different symbolic space, and, concurrently or later, becomes a nurturing environment for the symbolism of a newly emerging marketing system.

The symbolic relation and interpenetration of marketing systems requires profound analysis. Addressing the holistic view of intrinsic meanings, processes in marketing systems is especially important for the design of marketing systems (Layton 2007). To design a desirable system, one may put all necessary material (functional) structure together; however, without proper meaning infrastructure, this policy exercise may be doomed to failure.

\section{Conceptualizing Meaning}

\section{Symbolism in Marketing Systems}

Venkatesh (1999) notes that not only postmodernists but also many academics of other persuasions recognize that marketing has always been a sign system. Venkatesh argued that the symbolism of both production and marketing practices came to the forefront of academic attention because postmodernism provided a coherent structure to investigate meanings in macro contexts. He claims that the whole global economy in general, and marketing practices in particular, are part of the global sign system. Venkatesh considers consumption to be primary, whereas he accepts production as the means of churning out commodities and standard goods, which are then instilled with value in the contexts of use. In other terms, goods and services do not come with meanings ready for consumption but rather are imbued with meanings in the process of consumption (Vargo and Lusch 2004). Venkatesh's discussion of postmodernism provided specific guidelines to understand the relationship between marketing and symbolism in general terms. However, it did not go further to analyze the role of meanings in particular marketing systems. The questions like "how can we define meanings from a macro perspective?" or "what is the structure of symbolic marketing systems?" have received little attention not only in Venkatesh's paper but also generally in the macromarketing discipline.

Dixon (1991) gave a historical account of early macroeconomic thought by prominent economists such as François Quesnay, Karl Marx, Leon Walras, and Wassily Leontief. Analyzing the classic examples of economic abstractions, he notes that these studies emphasized only the static elements of economic systems while failing to recognize the role of marketing systems. In the process of searching for marketing in these classic analyses, Dixon came to the conclusion that "production ... [should be] seen as the transformation of inputs into satisfaction rather than into material attributes" (Dixon, 1991, 17). In other words, satisfaction is how consumers derive value from goods and it is always interpretive (Scitovsky 1976; Fournier and Mick 1999). Therefore, Dixon's conclusion can be understood as the fundamental condition of observing marketing systems: the researcher needs to investigate how system actors interpret marketing events. This is crucial because it sheds light on how the outcome of marketing systems operation, namely, product assortments, foster distinctive symbolic structures. Considering that the domain of marketing systems can be conditionally divided into production and consumption domains, the similar critique with respect to consumption processes is advanced by several researchers (Dolan 2002; Schaefer and Crane 2005). The orthodox conceptions of sustainable consumption are seen as too "static, individualistic, and rationalistic" (Dolan 2002, 170), while cultural research emphasizes the interpretive and interactive aspect of marketing systems (Arnould and Thompson 2005).

In contrast to macromarketing, micromarketing research can pride itself on seminal explorations of value, sign, and symbols at the level of dyadic interaction. Levy (1959) recognized the importance of meaning construction in marketing exchanges almost five decades ago. He argued that marketing transactions involve not only physical exchanges but also symbolic interactions. Since then the role of meaning and symbolism occasionally surfaced in seminal marketing papers (Bagozzi 1975; Webster Jr. 1992; Vargo and Lusch 2004). Bagozzi (1975) examined the conventional understanding of the marketing exchange concept. He identified several problems with the orthodox formulation, these problems originating from the concept being stripped off its social interactivity character. He argued that the concept of the marketing exchange in its orthodox form could be applied to those situations only when physical stuff and purely positive value are traded. The 
problematic view ignored various nonstandard situations ranging from marketer deception to coercive influence tactics to demarketing activities. Bagozzi stated that meanings of "positive, negative, or neutral actions" exercised by exchange actors were not considered under the orthodox perspective (Bagozzi 1974, 78). Another stream of research, Consumer Culture Theory, focused on meaning interpretation in fragmented social loci, such as communities, consumption tribes, microcultures, and value systems (Kozinets and Handelman 1998; McCracken 1988; Holt 1997; Kozinets 2002; Muniz Jr. and O'Guinn 2001; Thompson and Troester 2002). This micro-cultural research tends to address meanings from the perspective of an individual and puts less emphasis on macro-implications of market meanings. The exception is the research that discussed the impact of social, cultural, historical, and sign systems on personal life goals, aspirations, experiences, and identities (Thompson and Pollio 1994; Thompson and Troester 2002; Wenger 2000; Diamond et al. 2009). Furthermore, micromarketing research has paid little attention to the impact of cultural meanings on the natural and social environment. Nevertheless, Solomon (1983) argued that symbolism is actually a macro concept. His argument was that meaning could only be formed within a dyad (of sender and receiver) that he considered the minimum level of simplification. However, he called for a macro approach to study meanings: “ . . in general, a group is the appropriate level of analysis ... symbols are generated and learned at a relatively macro level” (p. 324).

\section{Macro Meaning of Meanings}

If meaning is a complex social and macro phenomenon, then the commonly accepted view that meaning is a personal psychological operation is somewhat flawed or at least an unwarranted simplification. Sociologists argue that meaning has social roots and that it is the outcome of social interaction (Solomon 1983; Geertz 1983; Bateson 1991; Luhmann 1995; Nicosia and Mayer 1976). Calling researchers to pay more attention to macro phenomena, Nicosia and Mayer (1976), in their article in the Journal of Consumer Research, expressed their discontent with the lack of research in this stream. They pointed out that the "... lack of attention to a society's consumption is surprising because macroeconomics has shown some of the advantages of studying production and consumption at the societal level rather than at the level of the single firm or the single household" (p. 65).

McCracken (1988) has taken a mid-range approach, arguing that meanings generated by society propagate from the cultural world to goods and then to consumers. He assumed that meanings have a univocal and transcendental essence that can be instilled into products and later derived by market actors. Differing from McCracken's structural approach, poststructuralists took a more interactive, and thus, macro approach. Their argument was that meanings arise within interactive relationships in various contexts (Holt 1997). The participative, dialogic principle of meaning was propounded by most reformist philosophers such as Nietzsche, Gadamer, Heidegger, Derrida, and Baudrillard (Schwandt 2003). In essence, these scholars argued that meaning is an activity rather than an entity, that is, a process of interpretation. It is existential, because there are no two separate steps, namely, first deriving meaning and then acting on this meaning. Instead, meaning is a practice in itself (Schwandt 2003). Bateson (1991) saw meaning as a "difference" as he argued that social systems are difference-centric, that is, operate on differences rather than on substances (entities). Bateson's theory of meaning emphasized differences that progressively arise at multiple levels of social reality. For instance, two objects that differ from each other in terms of a particular attribute could be seen exhibiting a meaning, that is, they are different from other objects in projecting a particular difference. Two similar objects also communicate the same meaning: they are different to other objects because of their similarity. The macro aspect of meaning is clarified in the light of Layton's (2007) discussion of marketing systems. Layton (2007) argued that "an essential starting point in the study of a marketing system is a determination of the boundaries of the marketing system (what is 'inside' and what is 'outside')" (p. 235). In other words, a marketing system creates a particular meaning space by performing two functions: (1) similar elements are aggregated and separated from other dissimilar elements; (2) differing but related elements are aggregated and separated from other unrelated elements. For example, a range of market exchanges across different industries is combined into a marketing system because of particular similarities (Bagozzi 1974). Interindustrial trade flows are aggregated into a national marketing system, again because of similarity (Layton 1981). At the same time, relationships between producers and consumers in itself can be considered a marketing system. In this context, producer and consumer practices are dissimilar but related (Venkatesh 1999). This insight forms the basis of the symbolism of a marketing system. In von Bertalanffy's (1972) words, “opposition or, indeed, fight among the parts within a whole ... forms a unity of higher order" (p. 408). Durkheim's (1858/1984) concept of organic solidarity is also helpful in this context. He observed that increasing specialization of labor within a societal milieu created the need for higher interdependence and integration. Durkheim compared specialized societal functions to the parts of individual's body: although they are radically different, they are all inherent and necessary parts of an organic unity. Hence, observed postmodernity trends such as fragmentalization of society and marketing activities do not mean the end of aggregated marketing systems (Venkatesh 1999; Firat and Venkatesh 1995). This process indicates the increasing importance of symbolic aspects of marketing systems as the base of organic solidarity between producers and consumers.

Moreover, Layton says that the process of system formation is synonymous to the process of boundary-marking. However, boundaries are not always real. Layton (2007) describes them as "fuzzy." In social contexts, boundaries are symbolic (Cohen 1985). Cohen (1985) gives a great number of practical examples of how community members act to create a meaning that automatically demarcates the difference between the actualized 
cultural system and the environment. This is consistent with von Bertalanffy's conceptualization of system boundaries, as he claims "it is difficult to tell what belongs to the living system and what does not ... [u]ltimately all boundaries are dynamic rather than spatial" (1972, p. 422).

\section{Symbolic Aspects of Marketing Systems}

In the previous section, the discussions of symbolism in marketing systems and the macro conceptualization of meanings have laid the loose principles of understanding meanings in the context of systems. However, these principles are not sufficient for analyzing a particular marketing system. Therefore, we need an operational definition of meaning, and also, a clear articulation of symbolism in marketing systems based on this definition.

\section{Symbolic Structure}

Borrowing from Luhmann (1995), the authors operationalize the concept meaning as the outcome of the interpretive process through which a group of system members differentiate their present action from action possibilities in the future (Luhmann 1995). This definition emphasizes meaning as a dynamic happening that includes not only the actual but also the possible in the form of the recognized courses of potential action.

The definition is not radically different to the conventional view of marketing systems. White (1981) defined the marketing system as comprising "all marketing related actions and transactions" (p. 11). The current definition adds a symbolic twist to White's view by suggesting that meaning in marketing systems represents the symbolic distinction between actual actions and potential actions that is drawn (interpreted) by system members together in marketing contexts. The conventional definition reads: a marketing system is "a network of individuals, groups, and/or entities linked directly or indirectly through sequential or shared participation in economic exchange that creates, assembles, transforms, and makes available assortments of products, both tangible and intangible, provided in response to customer demand" (Layton, 2007, 230). This definition emphasizes the production domain of marketing systems while acknowledging consumer input in the form of customer demand. Venkatesh (1999) called for directing attention to the role of consumption practices. This is not a radical idea. Marketing is also what consumers do if looked at from the consumer aspirations point of view (Kotler and Levy 1973). The notion of value co-creation effectively covers this change in emphasis (Vargo and Lusch 2004; Prahalad and Ramaswamy 2004). According to this notion, production does (can) not impute value in a product or service without involving consumers in the process. Consumers are involved in many ways. Consumers use, maintain, transform, improve, repair, adapt, dispose of, communicate on, socially interact about, and most importantly create meaning of the product. Layton's definition tells that assortments are created "in response to customer demand." From the meanings perspective, the assortments are not only the result of marketers' endeavor but also they are the function of consumer practices. Producers and consumers, via their practices, in their conformance, opposition, and amalgamation, produce (co-create) symbols within the marketing system. In other words, creating and consuming symbols goes hand-in-hand with creating and consuming goods.

\section{The Environment is Part of the System}

The notion that there is objective physical separation between the environment and the marketing system represents mere conceptual convenience rather than the fact that is supported by relevant empirical research. As the consequence of the direct application of Darwinian thought, Alderson's (1965) notion of survival (i.e., marketing systems adapt to turbulence in the environment) has been followed by convention (Reidenbach and Oliva 1983; Dixon and Wilkinson 1982; Dowling 1983). However, the incompatibility between Darwinian Theory and General Systems Theory has been discussed by von Bertalanffy (1972). He argued that systems are purpose driven and that they construct their own environment in their operations. Shapiro (1964) undertook an in-depth analysis of the Ontario Hog Board (an agricultural agency) and concluded that the assumption of total delineation between the system and the environment was not valid in explaining the situation under focus. His study revealed that the board executives refused to recognize imminent environmental threats that they did not perceive as threat. Rather they behaved according to their personal and individual apprehension (interpretation) of changes occurring at the time. Shapiro argued that the environment was not separable from the system and advocated the notion of "the relevant environment" (p. 120). Shapiro explains that "the environment is a dynamic rather than static component (!) of a system" (p. 120). It is notable that he believed that the environment is a component of the system rather than being outside of the system. To deal with this uncomfortable notion, Alderson (1965) developed the typology of the environment that included the proximate environment, the aspiration environment, and the ultimate environment.

The strong advocate of the marketing systems concept, Roger Layton (2007) divided the environment into the task environment and the institutional environment: the task environment included suppliers, intermediaries, customers, competitors, and other stakeholders, whereas the institutional environment comprised political, social, economic, and technological factors. Layton thought that the environment is associated with uncertainty and the ways this uncertainty is dealt with by system participants. His conclusion was that the system is an environment:

... the most important point to note is that the task environment for a decision maker at one level is largely if not entirely determined by the properties of the marketing system in which the business is embedded. The characteristics of the system 


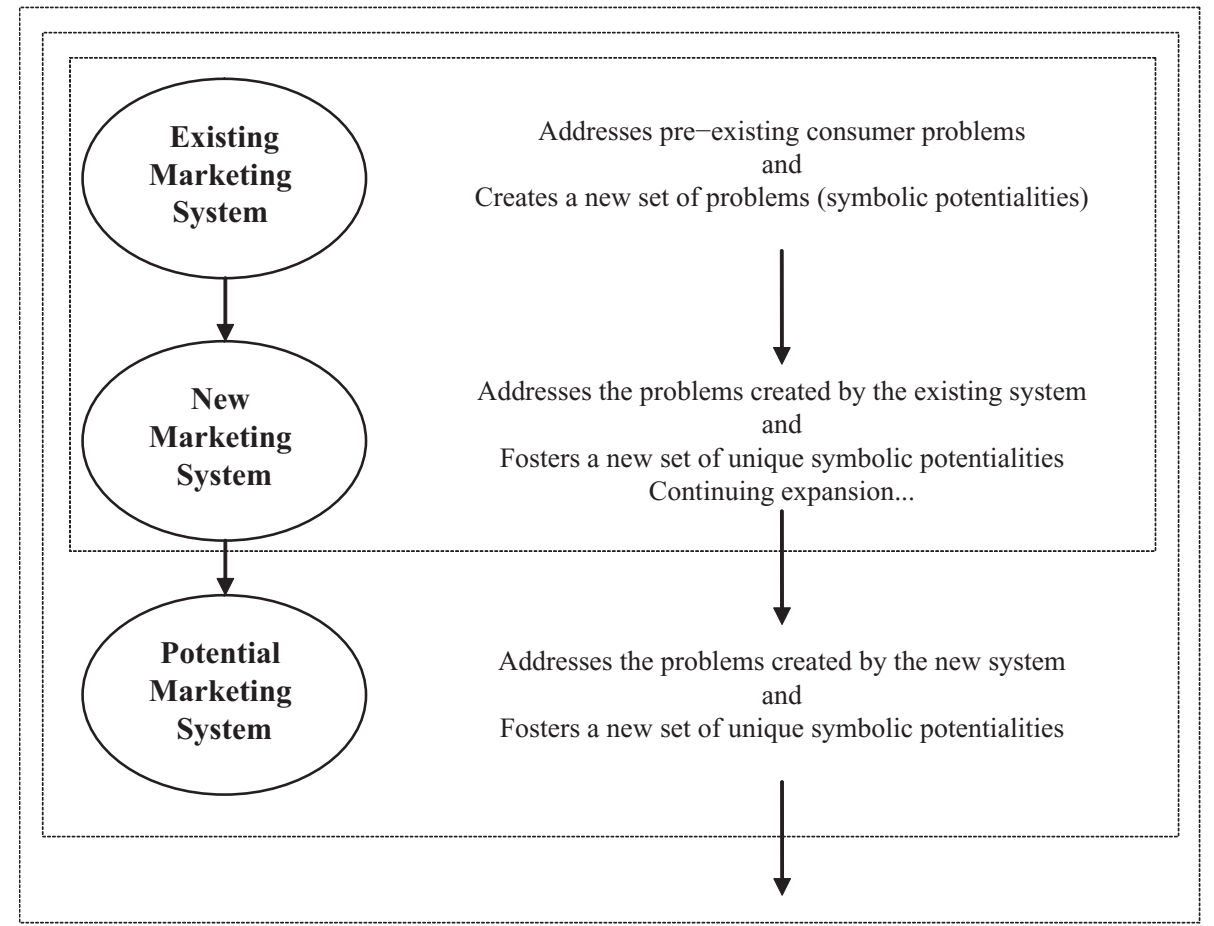

Figure I. The process of symbolic unfolding.

define the context in which the manager's decisions will take effect. (Layton, 2007, 239)

The interpretation of the environment is an active process implicit in the behavior of system actors and sometimes explicit in stories, narrative, and experiences related by them. An environmental turbulence or change is interpreted within the system and such interpretation is reflected in successive symbolic chains and networks (Daft and Weick 1984; Weick 2001). Not only are environmental changes selected (the proper term would be constructed) according to the priorities of a system but also the meanings of such constructions are unique. This process is called enactment (Weick, 1979). Enactment is not simply a direct, cognitive perception of the environment, rather it is the reflection of the environment that resonates in activities. The enacted environment is co-created within the system, as it becomes the result of interaction between social actors, their past behavior and experiences, and their perspectives (Luhmann 1995; Stern, Thompson, and Arnould 1998).

In order to be able to interpret the environment, the system must be able to interpret the self as being different from the environment (Luhmann 1995). Thus, the "picture" of the self is referenced against the enacted environment. While the self is recursively defined at each stage in reference to environmental events in a continuous fashion, the state of the system becomes highly volatile and unpredictable (von Foerster 2003). This means that the system's self-interpretation changes with the interpretation of the environment.

The noteworthy aspect of the aforementioned studies is that they agree that (1) the absolute environment that is objective is too complex and often is not straightforwardly interpretable; (2) the environment is always observed (enacted) by marketing systems, and thus becomes an inherent part of the system, that is, it represents the system's interpretation of its surrounding (Weick 1979), and (3) the observed environmental event can be differently interpreted depending on the perspective of the observer, thus, the same event, or a "social fact" (Geertz 1983), can inspire multiple meanings.

\section{Symbolic Unfolding}

What is the process of symbolic marketing system formation if the notions of meaning (as the distinction between actual and potential actions) and the environment (as a symbolically inherent part of marketing systems) are accepted? What we see is the process of symbolic unfolding through which existing marketing systems foster symbolic potentials that become an enacted environment for a newly emerging marketing system. The new marketing system, in turn, becomes part of the environment and enables new symbolic potentials to be exploited by ensuing marketing systems, and so on. This unfolding is captured diagrammatically in figure 1 .

One can find implicit discussion of symbolic unfolding in the extant research. Diamond et al. (2009) discuss how American Girl, a commercial powerhouse that sells dolls, doll clothing and accessories, and doll story books, has fostered a unique symbolic brand system (the authors call it "brand gestalt") in the U.S. market. The authors note that American Girl stands in symbolic opposition to excessive Barbification of children, 


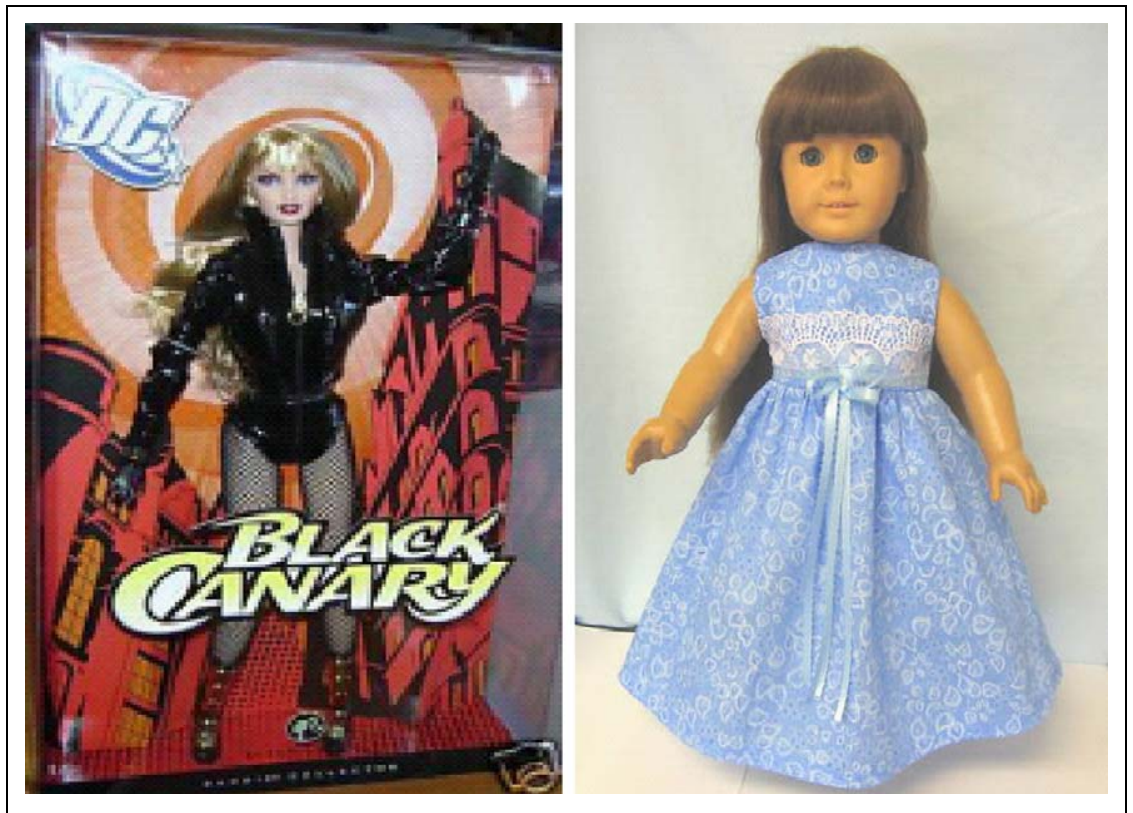

Figure 2. Barbie Black Canary and American Girl are different and related (Source: Author).

especially young girls. Barbie and American Girl are both dolls but display opposing values (figure 2).

The brand stands for "maintaining supportive and loving relationships with families and friends" (p. 122) and "perpetuation of domesticity" (p. 124) while confronting "the precocious sexualization" (p. 123). Looking back at the symbolic history of this brandscape, one may note that the cultural void that the American Girl brand fills up is the negative environmental spillover of modernity trends that originated at the turn of the last century. The trends such as industrialization, urbanization, globalization, and specifically, the sociocultural and political emancipation of women, have fostered conditions in which identities personified and promoted by toys like Barbie, Cabbage Patch Kids, or Bratz Dolls were relevant. At the time, the trends, related cultural transformations, and marketing systems that represented these changes were not necessarily negative. In fact, the modernity trends of female empowerment and emancipation supported by technological innovations freed women from labor-intensive contexts of domesticity (Wilkie and Moore 1999). The marketing systems (e.g., Barbie by Mattel Inc.) that operated in this cultural context have created a potential for alternative markets. From the symbolic perspective, the sexualization of young girls in dominant markets necessitated the counterculture that was fragmented but growing with the emphasis on domesticity. The market "yearned for a product that would ... allow little girls to be little for a little longer" (Diamond et al., 2009, 123). Interestingly, the same corporation can operate in the opposing symbolic systems: Mattel Inc. owns both Barbie and American Girl brands. Moreover, the authors visualize that the symbolic marketing operations based on the sexualization/domesticity distinction can be considered as a meta-marketing system that can in turn foster other potentialities. For example, the sexualization/domesticity dimension may prove to be projecting a narrow (myopic) picture of women's role in society, so alternative symbolic spaces such as women-as-entrepreneur, women-as-educator, or women-as-professional can be exploited by toy manufacturers and consumers.

The similar argument is propounded by Holt (2004). He argues that successful "iconic" brands (from our perspective these brands are the bases of expanding marketing systems) address common cultural anxieties and contradictions experienced by people in their everyday life. For instance, he describes how Budweiser symbolized the tension between the ideals of masculinity and the current reality in which "manhood" has become unattainable for many men due to emasculation and technology trends. What goes without mentioning is that acute symbolic contradictions are mostly generated or at least exacerbated by existing marketing systems. The meanings such as strong manhood, heroic masculinity, and rugged individualism represent the symbolic field where many brands thrive (e.g., Marlboro Man; Hirschman 2003; Holt and Thompson 2004). Budweiser has simply addressed the spillover effect of the dominant marketing system by addressing the impossibility of attaining manhood in modernized work contexts thus emphasizing deeply felt experiences of emasculation.

In this section, the authors have theorized the process through which marketing systems, in their operations, symbolically unfold into complex structures. These symbolic structures include alternative marketing systems that interpenetrate with existing systems as they share enacted environments. For example, the phenomenon that underlies female emancipation/sexualization trends is actual in the dominant marketing system; however, it also includes the potentiality in the form 
of domesticity sensitivity that is exploited by American Girl. Hence, the excessive marketing and consumer culture emphasis on one side of the symbolic distinction necessitates the consolidation of the other side that is represented by goods with new (forgotten old) symbolic meanings. In other words, the actuality of the marketing system enables symbolic potentialities in the form of opposing values. Another useful term that is used is a symbolic spillover effect (symbolic externality) that underlies the process of symbolic unfolding. It is seen in cultural contradictions and problems that are perpetuated by dominant systems. Holt (2004) calls such externalities a "tear" in the cultural fabric of society. Newly ensuing marketing systems attempt to mend these tears while inadvertently creating tears of their own. In this, symbolic unfolding can be represented by the metaphor of the wheel of meaning in marketing systems. The rotating wheel moves such that the system cycles but never returns to the starting place.

We have discussed a situation in which end consumers are strongly featured since they are clearly differently minded culturally influenced actors of the system, yet we also see symbolism in business marketing systems, and we also see that while purposeful marketing systems generate symbolic meanings, so do more informal, less-managed "emergent" systems (e.g., local community market events). Here, too, value is appreciated in choices among alternatives in which meaning is constructed in recognition of differences.

\section{Illustration}

In this section, the authors would like to illustrate the main aspects of meaning dynamics with the example of a particular marketing system. The marketing system under focus is the system of hybrid car marketing and consumption. The hybrid car has become the symbol (the identity myth in Holt's terms) that supposedly stitches back the cultural tear underlined by unsustainable mobility fears in society. The hybrid car is efficient, uses alternative fuel (self-generated electricity), and produces minimal harmful emissions. These are the functional aspects of the product, but what are the symbolic aspects of the system that support the meaning aura of the product?

The cultural context of this illustration is the widely recognized societal problem of sustainable mobility - the acute contradiction between the ideal mobility condition that is environmentally friendly and sustainable in the long term and the current reality of inefficient mobility trends - that resonates in personal experiences and anxieties of both managers and consumers. Most critics of consumer culture argue that the conventional automobile marketing systems, especially in industrialized countries, in the capacity of the mobility provisioning part of society, are not sustainable. It is estimated that there are approximately 700 million vehicles worldwide, which may increase up to a billion units in the next decade ("Driving Trends" 2007). The World Business Council for Sustainable Development (WBCSD 2004) estimates that personal transport activity (kilometers traveled) worldwide will grow by 1.7 percent per year in the next fifty years. In the same period, the total worldwide transport-related fuel use for all modes of vehicles will increase from 2.1 to 5 trillion $\left(10^{12}\right)$ liters gasoline-equivalent per year. For light duty vehicles, it is expected that energy efficiency per vehicle unit will improve by merely 18 percent by 2050 , which will not be enough to offset 123 percent increase in total transport activity in the same period. Mobility as a life issue occupies a significant share of human activity, and is thus an essential part of the global marketing system. The acute symbolic contradiction is echoed in the sustainable mobility dilemma, which is the situation in which a tension exists between the increasing needs for mobility and long-term environmental and societal health.

In the mainstream automobile industries, the scope of marginal innovation and lack of breakthrough ideas brought to market to solve long-term impacts of the system is staggering. The dominant focus has been to make automobiles stronger, bigger, and faster, while this focus has largely ignored a range of negative impacts on society, culture, and the environment. This trend has had its symbolic spillover. The opposing meaning has always been there, even though it was not well consolidated or represented by specific brands or product categories. In other words, the actuality of the system contained, and even fostered, a symbolic potentiality - the car (brand, category) that transcends the utilitarian priorities such as speed, cabin space, or motor power, while offering a means of transportation that is eco-friendly and runs on renewable clean fuel; the car that becomes the champion of the sustainable mobility cause; the car that provides an identity myth that helps to ease the mobility tension. The richer and more proliferated the traditional car assortments were, the more specific has become the view of an ideal alternative car technology. Available transportation assortments started to be perceived in the light of distinct categories - efficient, neutral, gas-guzzler - which represents the interpretation of sustainable mobility in informal consumer discourse. Marketers responded to such distinction through developing and offering fuel/emission-efficient vehicle technologies. The alternative system, which was a symbolic potentiality within the mainstream system, has largely come into existence as the result of Toyota Motor Corporation's introduction of the first hybrid car brand-Prius - in 1999 (Toyota Motor Corporation 2007). The competitors-Honda, Ford, General Motors, and DaimlerChrysler-have also jumped onto a "hybrid bandwagon" by developing their own versions of hybrid car brands. Figures 3 and 4 show extreme differences in the values of motor vehicle design and ownership.

The traditional and alternative systems are so interrelated that it would be difficult to analytically separate them (and their environments) from each other. One can realize that the traditional system has become a symbolic environment for the hybrid car system, and vice versa. Our extended observation of the hybrid car marketing systems revealed that the environment as seen from the hybrid car perspective is unique and intelligible to hybrid car enthusiasts only. In this, 


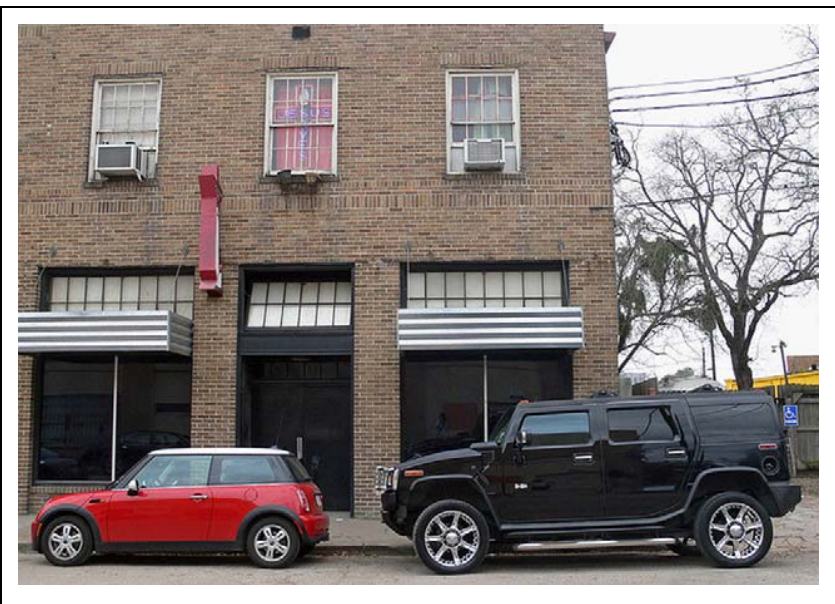

Figure 3. Big Car, Small Car (Jackson Myers 2007), Houston, TX. With Permission. Accessed at www.flickr.com/photos/j-a-x/ $357747019 \%$.

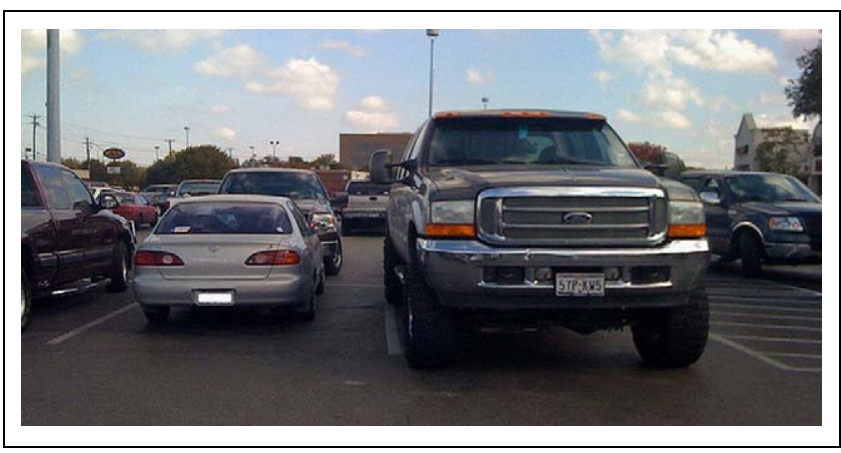

Figure 4. Texas is an amazing place (Andy 2008). Creative commons. Accessed at http://www.flickr.com/photos/andyonflickr/30054074l9/.

the environment is part of the system, that is, it is the interpretation of the system. The environmental objects like sport utility vehicles or large trucks are perceived to be the "enemy." At the same time, diesel and fuel-cell technologies are considered "rivals." Such macro factors as the natural environment, technology, and politics are assumed to be in the form that is shaped by non-green corporate practices. Not only is the hybrid car positioned to provide the "solution" to the spillover effects of the conventional system but also consumer practices evolve in opposition to those of the conventional system. The hybrid car driver (1) employs unique and customized driving techniques and strategies that are not applicable to conventional brands; (2) monitor the car's fuel efficiency while this is not possible in most conventional brands; (3) develops a "green" identity to uniquely position himself or herself among other drivers; (4) behaves differently in road situations (e.g., competes against gas-guzzlers); (5) is able to modify some aspects of the product. The irony is that the hybrid car system symbolically operates based on the constructed picture of supposedly gas-guzzling models and related practices that must be present in the marketplace

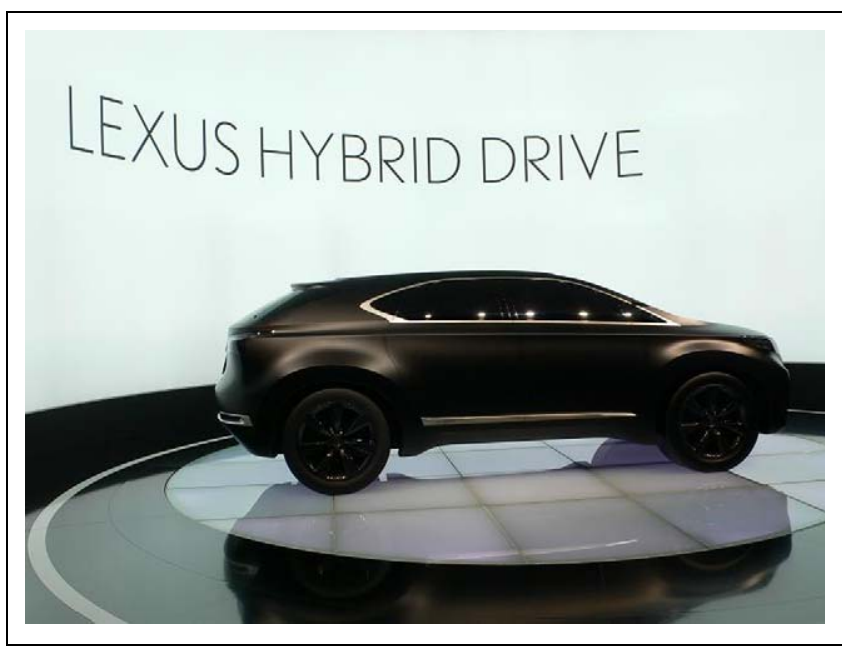

Figure 5. Lexus Hybrid Drive - gas-guzzler SUVs are also turning into friendly Hybrids. The new symbolic system overwhelms the existing system. (Ascaron 2008) Wiki Commons.

as a reference point. Both producers and consumers can only define hybrids and their own practices to be green or sustainable when they can see significant differences in relation to conventional vehicle categories and related practices. The hybrid car is efficient (which is good for ecology) because it is more fuel efficient than a sport utility vehicle. The hybrid car is green because it produces less emissions compared to a conventional sedan. The hybrid driver is green because he or she can potentially maximize the miles driven per fuel gallon burned through the use of hybrid driving techniques while this is not possible with other vehicle categories.

The existence and meaning of the hybrid vehicle defines the symbolic dimension of the system for "SUV" drivers. For example, bloggers have stated that "There are very practicle (sic) purposes for SUVs. Just because you don't like people who have the means to transport their families in a full-size SUV doesn't mean we should discriminate against them... People who drive large SUVs have rights too!" and "Why do people act like SUVs and SUV drivers are the spawn of satan (sic)? Do you do everything you can to be energy efficient? There is a hell of a lot more to conserving energy than the vehicle you drive.... How many of you SUV haters can even see the forest for the trees? How many SUV haters have spent a single night in the wilderness with complete disconnect (sic) from the modern world and just sat their (sic) taking it all in? .... why don't SUV haters step off their high horses and examine their own faults before they judge others based on one, and only one, of a persons (sic) many consumer choices" (Autoblog.com 2006). The symbolic unfolding process is at work: instead of completely solving the mobility dilemma, the hybrid car marketing system simply exposes paradoxes which as potentialities can foster new alternative marketing systems. One such of these paradoxes is the immanence of "gas-guzzlers" as reference: 
Toyota can simply make its conventional SUVs more "guzzling" and the hybrids more "saving" to make these categories differentiated and thus visibly meaningful to different segments. Thus, the symbolic potentiality that transcends beyond the more/less fuel efficient dimension is being formed, and the technologies such as the plug-in electric hybrid's fuel cell can enter as another myth to address such a tension. In figure 5, the authors see that while highly significant differences were the starting point, the distinctions can be overcome to create a new hybrid-in this case a hybrid Hybrid!

\section{Discussion and Conclusions}

The analysis of symbolism complements rather than substitutes the traditional analyses of marketing systems. The authors argue that the symbolic dimension of marketing systems is important and understanding meaning from the macromarketing perspective is crucial. In this article, the authors propose that meaning in a marketing system represents the symbolic relation of market actors' actions and practices to potentialities (e.g., symbolic spillovers) that these practices tend to generate. The existing marketing system expands via employing such potentialities; in other words, alternative marketing subsystems are formed on the basis of products that symbolize societal contradictions and personal anxieties created by symbolic spillovers.

Layton (2007) commented that product assortments as the output of marketing systems influence the standard of living. From the symbolic perspective, the output of the marketing system is meaning (in a macro sense) that grants a vital sense of societal purpose to product assortments. How can meaning (e.g., symbols and signs) affect the standard of living? The philosophy school, existentialism, provides an epistemological foundation to see human beings as if they are on a lifelong mission of search for the meaning of life (Sartre 1992; Kierkegaard 2000). Sartre (1992) argued that a successful personal solution to the problem of understanding the purpose of one's own existence reduces fundamental anxiety ("nausea" in Sartre's terms) felt by the human being living in society. Macromarketing research shows that quality-of-life perceptions are moderated by cultural beliefs - a dominant social paradigm - the large part of which is constituted by meanings constructed in marketplaces (Kilbourne et al. 1997). In this article, the authors argue that meanings become crystallized in products that address vital societal problems and contradictions. Marketing system actors reduce their existential anxieties via the production, use, and disposal of meaning-laden product assortments. Moreover, they literally construe their lives in symbolic consumption. This is exhibited in practices, rituals, and interactions they develop in relation to the product. However, seeking a solution to the profound and in some ways complex societal problems via attributing meaning to product assortments generates yet further alternative societal contradictions. In other words, we see that paradoxes are contained in chosen solutions. In the symbolic dimension, the quest to improve the standard of living via offering product assortments that tackle deep societal problems is not an evolving process; rather it is cyclical. Giddens (1991) argued that in modern societies, the task of attaining the ideal self-identity becomes the unending quest of marginal improvements. In the same way, marketing systems at least in their symbolic form may never achieve perfection but infinitely oscillate between problem solution and generation.

The design of marketing systems at both highly aggregated and disaggregated levels is likely to be successful if careful consideration is given to the symbolic nature of systems. Heavily designed marketing systems may fail perhaps only because meanings projected by these systems may not be adequate. The failure of the centrally planned economic system involving the former Soviet Union and satellite Eastern European countries is an example. We cannot argue that the command economy was meaningless to market system actors; rather the meanings intended by planners (e.g., Gosplan) were not relevant at the level of system actors. Hence, any design activity (or market experiment) needs take into account the fact that meaninglessness is not an option in developing a marketing system - the system will always have its symbolic dimension-which must be interpretively understood rather than rationally explained. Holt's (2004) book How Brands Become Icons: The Principles of Cultural Branding is replete with stories on how the designers of disaggregate marketing systems (e.g., business corporations developing new markets) either struggle to comprehend or successfully exploit symbolism rooted in brand consumption practices. Holt's story of Quaker's purchase and (mis)management of the Snapple brand is enlightening. Snapple originally represented alternative, low-key, counterintuitive, and hippie lifestyles and sold through marginal marketing channels such as corner shops and local pizza chains (this is also documented by McCracken 2005). It stood in clear contrast to mainstream brands such as Gatorade sold through mass merchandisers and big supermarket chains. However, Holt argues that the Snapple's symbolic value was destroyed by corporate planners who decided to mass commercialize the brand. Holt shows that the managers have possibly taken most of the relevant design factors into account apart from the meaning of the brand. This led them to a complete failure with this product.

Layton's (2007) example of the Ghanaian Makola Market also poses several important questions with regard to the design versus the meaning of the marketplace to its participants. Layton retells the story (see also McMillan 2002) of the government completely bulldozing the Makola Market in 1979, and then in a matter of a week merchants and consumers returning and rebuilding the same structures on the same spot. One can argue that the Ghanaian government was engaged in a kind of purposeful market system design activity when they decided to destroy the market. Most possibly, for them this particular marketing system represented visible aspects of the market such as the place, buildings, and people. However, the symbolic aspect is invisible; hence, it is not amenable to the power of the "bulldozer." The authors 
think that the Ghanaian design experiment would have been successful if they have offered (developed) an alternative system of market exchange that has the same symbolic status as the Makola Market. Clearly, this task is not as simple as bulldozing the visible aspects of existing perhaps inefficient marketing systems.

\section{Declaration of Conflicting Interests}

The author(s) declared no potential conflicts of interest with respect to the research, authorship, and/or publication of this article.

\section{Funding}

The author(s) received no financial support for the research, authorship, and/or publication of this article.

\section{References}

Alderson, Wroe. 1965. Dynamic marketing behavior; A functionalist theory of marketing. Homewood, IL: R.D. Irwin.

Arndt, Johan. 1986. Shared symbols, meaning, and ways of life in interorganizational networks. In Marketing management technology as a social process, ed. G. Fisk. New York: Praeger Publishers.

Arnould, Eric J., and Craig J. Thompson. 2005. Consumer culture theory (CCT): Twenty years of research. Journal of Consumer Research 31:868-82.

Bagozzi, Richard P. 1974. Marketing as an organized behavioral system of exchange. Journal of Marketing 38:77-81.

- 1975. Social exchange in marketing. Journal of the Academy of Marketing Science 3:314-28.

Bateson, Gregory. 1991. A sacred unity: Further steps to an ecology of mind. New York: Cornelia \& Michael Bessie Book.

Bernstein, Richard J. 1983. Beyond objectivism and relativism: Science, hermeneutics, and praxis. Philadelphia: University of Pennsylvania Press.

Cohen, Anthony P. 1985. The symbolic construction of community. London: Tavistock Publications.

Daft, Richard L., and Karl E. Weick. 1984. Toward a model of organizations as interpretation systems. The Academy of Management Review 9:284-95.

Dahringer, Lee D., and Marye T. Hilger. 1985. A comparative study of public food marketing as viewed by consumers in Mexico and India. Journal of Macromarketing 5:69-79.

Diamond, Nina, John F. Sherry Jr., Albert M. Muniz Jr, Mary Ann McGrath, Robert V. Kozinets, and Stefania Borghini. 2009. American Girl and the brand gestalt: Closing the loop on sociocultural branding research. Journal of Marketing 73:118-34.

Dixon, Donald F. 1991. Marketing structure and the theory of economic interdependence: Early analytical developments. Journal of Macromarketing 11:5-18.

Dixon, Donald F., and I. F. Wilkinson. 1982. The marketing system. Australian management studies. Melbourne: Longman Cheshire.

Dolan, Paddy. 2002. The sustainability of "sustainable consumption." Journal of Macromarketing 22:170-81.

Dowling, Grahame R. 1983. The application of general systems theory to an analysis of marketing systems. Journal of Macromarketing $3: 22-32$.
"Driving Trends." 2007. Driving trends. HybridCars 2007 (cited March 30, 2007). Available from http://www.hybridcars.com/ cat_featured/driving-trends.html

D'Rozario, Denver, and Jerome D. Williams. 2005. Retail redlining: Definition, theory, typology and measurement. Journal of Macromarketing 25:175-86.

Durkheim, Emile. 1858/1984. The division of labor in society. New York: The Free Press.

Etgar, Michael. 1983. A failure in marketing technology transfer: The case of rice distribution in the Ivory Coast. Journal of Macromarketing 3:59-68.

Firat, Fuat A., and Alladi Venkatesh. 1995. Liberatory postmodernism and the reenchantment of consumption. Journal of Consumer Research 22:239-67.

Fisk, George. 1967. Marketing systems: An introductory analysis. New York: Harper \& Row.

Fournier, Susan, and David Glen Mick. 1999. Rediscovering satisfaction. Journal of Marketing 63:5-23.

Geertz, Clifford. 1983. Local knowledge: Further essays in interpretive anthropology. New York: Basic Books.

Giddens, Anthony. 1991. Modernity and self-identity: Self and society in the late modern age. Cambridge: Polity.

Hirschman, Elizabeth C. 2003. Men, dogs, guns, and cars: the semiotics of rugged individualism. Journal of Advertising 32:9-22.

Holbrook, Morris B. 1995. The three faces of elitism: postmodernism, political correctness, and popular culture. Journal of Macromarketing 15:128-65.

Holt, Douglas B. 1997. Poststructuralist lifestyle analysis: Conceptualizing the social patterning of consumption in postmodernity. Journal of Consumer Research 23:326-50.

- 2004. How brands become icons: The principles of cultural branding. Boston, MA: Harvard Business Press.

Holt, Douglas B., and Craig J. Thompson. 2004. Man-of-action heroes: The pursuit of heroic masculinity in everyday consumption. Journal of Consumer Research 31:425-40.

Ingene, Charles A. 1983. Consumer expenditures and consumer satisfaction with the spatial marketing system. Journal of Macromarketing 3:41-54.

Jones, D. G. Brian, and Eric H. Shaw. 2006. Historical research in the journal of macromarketing, 1981-2005. Journal of Macromarketing 26:178-92.

Kierkegaard, Søren. 2000. The essential Kierkegaard. Princeton University Press.

Kilbourne, William E., Pierre McDonagh, and Andrea Prothero. 1997. Sustainable consumption and the quality of life: A macromarketing challenge to the dominant social paradigm. Journal of Macromarketing 17:4-21.

Kotler, Philip, and Sidney J. Levy. 1973. Buying is marketing too! Journal of Marketing 37:54-59.

Kozinets, Robert V. 2002. The field behind the screen: Using netnography for marketing research in online communities. Journal of Marketing Research 39:61-72.

Kozinets, Robert V., and Jay Handelman. 1998. Ensouling consumption: A netnographic exploration of the meaning of boycotting behavior. Advances in Consumer Research 25:475-80. 
Layton, Roger A. 1981. Trade flows in macromarketing systems. Journal of Macromarketing 1:35-48.

- 2007. Marketing systems - A core macromarketing concept. Journal of Macromarketing 27:227-42.

Layton, Roger A., and Sanford Grossbart. 2006. Macromarketing: Past, present, and possible future. Journal of Macromarketing 26:193-213.

Levy, Sidney J. 1959. Symbols for sale. Harvard Business Review $37: 117-24$.

Luhmann, Niklas. 1989. Ecological communication. Cambridge, UK: Polity Press.

- 1995. Social systems, writing science. Stanford, CA: Stanford University Press.

Markin, Rom J., and Calvin P. Duncan. 1981. The transformation of retailing institutions: Beyond the wheel of retailing and life cycle theories. Journal of Macromarketing 1:58-66.

McCracken, Grant. 1988. Culture and consumption: New approaches to the symbolic character of consumer goods and activities. Bloomington: Indiana University Press.

McCracken, Grant. 2005. Culture and consumption II: Markets, meaning, and brand management. Bloomington: Indiana University Press.

McMillan, John. 2002. Reinventing the bazaar-A natural history of markets. New York: W. W. Norton \& Company.

Meade II, William K, and Robert W. Nason. 1991. Toward a unified theory of macromarketing: A systems theoretic approach. Journal of Macromarketing 11:72-82.

Mittelstaedt, John D., William E. Kilbourne, and Robert A. Mittelstaedt. 2006. Macromarketing as agorology: Macromarketing theory and the study of the agora. Journal of Macromarketing 26:131-42.

Mittelstaedt, Robert A., and Robert E. Stassen. 1994. Structural changes in the phonograph record industry and its channels of distribution, 1946-1966. Journal of Macromarketing 14:31-44.

Muniz Jr., Albert M., and Thomas C. O'Guinn. 2001. Brand community. Journal of Consumer Research 27:412-33.

Nicosia, Francesco M., and Robert N. Mayer. 1976. Toward a sociology of consumption. Journal of Consumer Research 3:65-75.

Olsen, Janeen E., and Kent L. Granzin. 1990. Economic development and channel structure: A multinational study. Journal of Macromarketing 10:61-77.

Ortiz-Buonafina, Marta. 1992. The evolution of retail institutions: A case study of the Guatemalan retail sector. Journal of Macromarketing 12:16-27.

Prahalad, C. K., and Venkatram Ramaswamy. 2004. The future of competition: Co-creating unique value with customers. Boston, MA: Harvard Business School Publishing.

Reidenbach, Eric R., and Terence A. Oliva. 1983. Toward a theory of the macro systemic effects of the marketing function. Journal of Macromarketing 3:33-40.

Sartre, Jean-Paul. 1992. Being and nothingness: A phenomenological essay on ontology. New York: Washington Square Press.

Schaefer, Anja. 2005. Some considerations regarding the ecological sustainability of marketing systems. Electronic Journal of Radical Organisation Theory 9. Available from http://www.mngt.waikato. ac.nz/ejrot/Vol9_1/Schaefer.pdf

Schaefer, Anja, and Andrew Crane. 2005. Addressing sustainability and consumption. Journal of Macromarketing 25:76-92.
Schwandt, Thomas A. 2003. Three epistemological stances for qualitative inquiry: Interpretivism, hermeneutics, and social constructionism. In The landscape of qualitative research: Theories and issues, ed. N. K. Denzin and Y. S. Lincoln. Thousand Oaks: SAGE.

Scitovsky, Tibor. 1976. The joyless economy: An inquiry into human satisfaction and consumer dissatisfaction. New York: Oxford University Press.

Shapiro, Stanley J. 1964. The survival concept and the nonprofit behavior system. In Theory in marketing, ed. R. Cox, W. Alderson, and S. J. Shapiro. Homewood, IL: Richard D. Irwin.

Solomon, Michael R. 1983. The role of products as social stimuli: A symbolic interactionism perspective. Journal of Consumer Research 10:319-29.

Speece, Mark. 1990. Evolution of ethnodominated marketing channels: Evidence from Oman and Sudan. Journal of Macromarketing 10:78-93.

Stern, Barbara B., Craig J. Thompson, and Eric J. Arnould. 1998. Narrative analysis of a marketing relationship: The consumer's perspective. Psychology \& Marketing 15:195-214.

Thompson, Craig J., and Howard R. Pollio. 1994. The spoken and the unspoken: A hermeneutic approach to understanding the cultural viewpoints that underlie consumers' expressed meanings. Journal of Consumer Research 21:432-53.

Thompson, Craig J., and Maura Troester. 2002. Consumer value systems in the age of postmodern fragmentation: The case of the natural health microculture. Journal of Consumer Research 28:50571.

Toyota Motor Corporation. 2007. History of Toyota. Toyota Motor Corporation 2007 (cited March 30, 2007). Available from http:// www.toyota.co.jp/en/history/index.html

Tuninga, Ronald S. J. 1991. The hierarchical structure of intermediate markets: A new approach to the analysis of trade flow tables. Journal of Macromarketing 11:55-62.

van Dam, Ynte K., and Paul C. Apeldoorn. 1996. Sustainable marketing. Journal of Macromarketing 16:45-56.

Vargo, Stephen L., and Robert F. Lusch. 2004. Evolving to a new dominant logic for marketing. Journal of Marketing 68:1-17.

Venkatesh, Alladi. 1999. Postmodernism perspectives for macromarketing: An inquiry into the global information and sign economy. Journal of Macromarketing 19:153-69.

von Bertalanffy, Ludwig. 1972. The history and status of general systems theory. Academy of Management Journal 15:407-26.

von Foerster, Heinz. 2003. Understanding understanding: Essays on cybernetics and cognition. New York: Springer-Verlag New York, Inc.

von Foerster, Heinz, and Bernhard Poerksen. 2001. Understanding systems. New York: Kluwer Academic/Plenum Press.

Webster Jr., Frederick E. 1992. The changing role of marketing in the corporation. Journal of Marketing 56:1-17.

Weick, Karl E. 1979. The social psychology of organizing. Reading, MA: Addison-Wesley.

- 2001. Making sense of the organization. Oxford, UK; Malden, MA: Blackwell Publishers.

Wenger, Etienne C. 2000. Communities of practice and social learning systems. Organization 7:225-46. 
White, Phillip D. 1981. The systems dimension in the definition of macromarketing. Journal of Macromarketing 1:11-13.

Wilkie, William L., and Elizabeth S. Moore. 1999. Marketing's contributions to society. Journal of Marketing 63:198-218.

Wittgenstein, Ludwig. 1963. Philosophical investigations. Oxford: Blackwell.

World Business Council for Sustainable Development. 2004. Mobility 2030: Meeting the challenges to sustainability. Geneva: WBCSD.

\section{Bios}

Djavlonbek Kadirov is a senior lecturer at the School of Business at the Eastern Institute of Technology, Hawke's Bay, New Zealand.
He received his $\mathrm{PhD}$ from the University of Waikato. His research interests include macromarketing issues, specifically, marketing systems conceptualization, sustainable marketing, societal impact of marketing, meanings in consumer culture, and time-series modeling.

Richard J. Varey is a Professor of Marketing and former Chair of the Department of Marketing at the Waikato Management School, the University of Waikato, Hamilton, New Zealand. His research and teaching interests are marketing and society, relationship marketing, and marketing interaction. He was Editor of the Australasian Marketing Journal in 2006-2008 and is presently Associate Editor (Asia-Pacific) of the Journal of Customer Behaviour. 